\title{
Cold-modulated small proteins abundance in winter triticale ( $x$ Triticosecale, Wittm.) seedlings tolerant to the pink snow mould (Microdochium nivale, Samuels \& Hallett) infection
}

\author{
Gabriela Gołębiowska¹, Emilia Bonar², Kaveh Emami³ and Maria Wędzony ${ }^{1}$ \\ 1Pedagogical University of Cracow, Institute of Biology, Department of Cell Biology and Genetics, Kraków, Poland; 2Jagiellonian University, \\ Faculty of Biochemistry, Biophysics and Biotechnology, Department of Analytical Biochemistry, Kraków, Poland; 3University of Newcastle Upon \\ Tyne, School of Biology, Institute for Research on Environment and Sustainability, NE1 7RU, UK
}

Two winter triticale ( $\mathrm{x}$ Triticosecale Wittmack) model cultivars: Hewo (tolerant to pink snow mould) and Magnat (sensitive) were used to test the effect of cold-hardening ( 4 weeks at $4^{\circ} \mathrm{C}$ ) on soluble $\leq 50 \mathrm{kDa}$ protein profiles of the seedling leaves. The presence and abundance of individual proteins were analysed via two-dimensional gel electrophoresis (2-DE) and Surface-Enhanced Laser Desorption/lonization Time-of-Flight (SELDI-TOF). Up to now, no proteomics analysis of triticale response to hardening has been performed. Thus, the present paper is the first in the series describing the obtained results. In our experiments, the exposure to the low temperature-induced only quantitative changes in the leaves of both cultivars, causing either an increase or decrease of 4-50 kDa protein abundance. Among proteins which were cold-accumulated in cv. Hewo's leaves, we identified two thioredoxin peroxidases (chloroplastic thiol-specific antioxidant proteins) as well as mitochondrial$\beta$-ATP synthase subunit and ADP-binding resistance protein. On the contrary, in hardened seedlings of this genotype, we observed the decreased level of chloroplastic RuBisCO small subunit PW9 and epidermal peroxidase 10. Simultaneous SELDI-TOF analysis revealed several low mass proteins better represented in cold-hardened plants of tolerant genotype in comparison to the sensitive one and the impact of both genotype and temperature on their level. Based on those results, we suggest that indicated proteins might be potential candidates for molecular markers of cold-induced snow mould resistance of winter triticale and their role is worth to be investigated in the further inoculation experiments.

Key words: Cereals, cold-hardening, pathogen tolerance, thiol-specific peroxidases, two-dimensional gel electrophoresis, Surface-Enhanced Laser Desorption/Ionization Time-of-Flight

Received: 14 April, 2019; revised: 28 April, 2019; accepted: 22 July, 2019; available on-line: 10 September, 2019

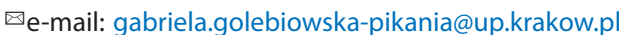

Acknowledgements of Finanacial Support: This work was supported by $5^{\text {th }}$ UE Framework Programme project CROPSTRESS QLAM-2001-00424 as well as MNiSW project NN310 140239.

Abbreviations: AFPs, Anti-Freeze Proteins; IEF, Isoelectrofocusing; LTPs, Lipid-Transfer Proteins; MALDI-TOF, Matrix-Assisted Laser Desorption/Ionization Time-of-Flight; PR, Pathogenesis-Related proteins; Prx, peroxiredoxin; ROS, reactive oxygen species; SAR, Systemic Acquired Resistance; SELDI-TOF, Surface-Enhanced Laser Desorption/lonization Time-of-Flight; 2-DE, two-dimensional gel electrophoresis

\section{INTRODUCTION}

According to the regular reports, pink snow mould resulting from Microdochium nivale (Samuels \& Hallett) infection is one of the most serious diseases of winter cereals and grasses in temperate and cold climatic areas (Tronsmo et al., 2001; Prończuk et al., 2003, Ren et al., 2015, Stricker et al., 2017). M. nivale infects also winter triticale ( $x$ Triticosecale Wittmack), the man-made hybrid cereal, lowering the quality and quantity of its yield. Variable levels of triticale pink snow mould infection were reported from field experiments and from tests under control conditions (Cichy \& Maćkowiak, 1993; Hudec \& Bokor, 2002; Sliesaravičius et al., 2006; Gołębiowska \& Wędzony, 2009; Zhukovsky \& Ilyuk, 2010; Szechyńska et al., 2011; 2013; Arseniuk \& Góral, 2015).

In response to fungal attack and other stresses, higher plants can produce special proteins belonging to Pathogenesis-Related proteins (PR-proteins), which are classified into PR1-17 families (Okushima et al., 2000). They are expressed mainly in leaves, but also in other plant organs (Van Loon, 1997; Van Loon, 2006). Among others, glucanases (PR2) and chitinases (PR3, 4, 8 and 11) are suggested to decompose fungal cell wall, while PR1, peroxidases (PR11) and thaumatins function as antibiotics, membrane permeabilizers of the invaders and inhibitors of fungal proteases. Their activity can inhibit pathogenesis/infection progress (Van Loon \& Van Strien, 1999). PR-proteins can be a part of the first defensive barrier since they are produced in cell wall appositions at the early stage of pathogenesis before concise host-pathogen contact. They are also suggested to play a role in Systemic Acquired Resistance SAR (Tuzun \& Somanchi, 2006). A potential role in defensive response to $M$. nivale infection was proposed for catalase and peroxidase (Gołębiowska et al., 2011), chitinase (Żur et al., 2013) and thiol-specific antioxidant protein (Gołębiowska-Pikania \& Golemiec, 2015) in winter triticale; chitinase, endochitinase, 1,3- $\beta$ glucanase in winter rye (Hiilovaara-Teijo et al., 1999; Yeh et al., 2000); chitinase, endochitinase, 1,3- $\beta$ glucanase, PR1-a protein and peroxidase in winter wheat (Ergon et al., 1998) and thaumatin-like proteins in winter wheat (Kuwabara et al., 2002). The predicted molecular mass of those proteins ranges from 13 to $50 \mathrm{kDa}$. Despite the above studies, the 2-DE analysis of cereal PR protein profiles has not been performed so far.

As many authors proved, cold-hardening is the most important factor activating cereal defense responses to M. nivale infection (Laroche 1997; Ergon et al., 1998; Browne et al., 2008; Gołębiowska \& Wędzony, 2009; 
Dubas et al., 2011; Szechyńska et al., 2011, 2013, 2015). The maximal resistance was detected exclusively in cold-hardened plants but genotypes differ in their ability to obtain cold-induced resistance (Hömmo, 1994; Ergon et al., 1998; Gołębiowska \& Wędzony, 2009; Gołębiowska \& Golemiec, 2015). The relationship between frost resistance and snow mould resistance remains indistinct (Ergon et al., 1998; Ergon \& Tronsmo, 2006). Cold-hardening enhances snow mould resistance since stronger and more rapid transcription of genes encoding different PR-proteins were found in hardened compared to unhardened winter wheat plants after $M$. nivale inoculation (Ergon et al., 1998; Hiilovaara-Teijo et al., 1999; Gaudet et al., 2000; Kuwabara et al., 2002; Gaudet et al., 2003a,b). However, the complete influence of cold on PR activity is prominent especially in inoculated plants (Ergon et al., 1998; Gaudet et al., 2000). PR-proteins accumulating in the apoplast of winter rye during cold acclimation were shown to exhibit glucanase and chitinase activity in addition to antifreeze activity (Hiilovaara-Teijo et al., 1999; Yeh et al., 2000) unlike PR proteins produced at warmer temperatures. Additionally, winter rye AFPs (Anti-Freeze Proteins) were apparently isoforms of PR-proteins specifically induced at low temperature (Yeh et al., 2000). Moreover, in winter wheat experiments, a thaumatin-like protein was induced by cold (Kuwabara et al., 2002). Gene transcription of defensin, purothionine, and LTPs (Lipid-Transfer Proteins) was maximal after 2-3 weeks of cold-hardening and remained constant for 7 days of dehardening (Gaudet et al., 2003a). Expression of LTPs mentioned above was observed in non-hardened plants neither in laboratory nor under the field conditions.

Our previous investigations documented genotype-dependent, increased resistance of triticale after 4 weeks of cold-hardening at $4^{\circ} \mathrm{C}$ (Gołębiowska \& Wędzony, 2009) and antioxidative enzyme involvement in the mechanisms of cold-induced snow mould resistance (Gołębiowska et al., 2011; Gołębiowska \& Golemiec, 2015; Gawrońska \& Gołębiowska, 2016). However, no proteomic analysis of the reaction of triticale to cold-hardening has been done so far. Thus, extensive studies at the molecular level were performed and the present paper is the first in the series describing the obtained results. For that purpose, two winter triticale cultivars selected in the previous research (Gołębiowska \& Wędzony, 2009): snow mould-tolerant cv. Hewo and sensitive cv. Magnat were used as the plant model to test the effect of cold-hardening on soluble protein patterns in seedling leaves. In this paper, we proposed the hypothesis that the protein expression profiles of those two genotypes differ after cold treatment and that some of the changes caused by hardening might be significant under snow cover and pathogen infection. The presence and amount of individual proteins were analyzed via 2 -DE in fully-hardened plants in comparison to the control non-hardened seedlings. Parallel analyses were also performed via Surface-Enhanced Laser Desorption/Ionization Time-ofFlight (SELDI-TOF).

\section{MATERIALS AND METHODS}

Plant material. Two winter hexaploid triticale $(x$ Triticosecale Wittmack, $2 \mathrm{n}=6 \mathrm{x}=42$ ) cultivars, significantly different in respect to their cold-induced resistance to $M$. nivale infection in the field and under controlled conditions (Gołębiowska \& Wędzony, 2009) were used in the study: tolerant cv. Hewo (Strzelce Plant Breeding - IHAR Group Ltd., Poland) and sensitive cv. Mag- nat (Danko Plant Breeders Ltd., Poland). Plants were surface-sterilized and grown as described previously (Gołębiowska \& Wędzony, 2009) in the climatic chamber at $8 \mathrm{~h} / 16 \mathrm{~h}$ (day/night) photoperiod, at $16^{\circ} \mathrm{C} / 12^{\circ} \mathrm{C}$, $\mathrm{RH}=60-67 \%$, for 7 days. On the 7 th day, plants were supplemented once with Hoagland \& Arnon's (1938) sterile medium, $0.05 \mathrm{~m}^{3}$ per pot.

Starting from the $8^{\text {th }}$ day after potting, half of the plants were subjected to the prehardening for 14 days at $12^{\circ} \mathrm{C} / 12^{\circ} \mathrm{C}$, with $8 \mathrm{~h} / 16 \mathrm{~h}$ (day/night) photoperiod. Then, they were hardened at $4^{\circ} \mathrm{C} / 4^{\circ} \mathrm{C}$ for 28 days in the same light regime. The remaining control, non-hardened plants were grown constantly at $16^{\circ} \mathrm{C} / 12^{\circ} \mathrm{C}, 8 \mathrm{~h} / 16 \mathrm{~h}$ (day/night) photoperiod, until achieving the same stage of seedling development according to the Zadok's scale (Zadok et al., 1974) as the fully cold-hardened plants, i.e. for the next 14 days (21 days from potting in total).

Plant sampling. The protein analysis was conducted on fully-expanded leaves (2nd in appearance) of 5 different seedlings of each genotype from the control non-hardened and the cold-hardened plants. Freshly cut samples were immediately frozen in liquid nitrogen and stored at $-80^{\circ} \mathrm{C}$ until protein extraction. Analyses were performed in 3 biological replicates consisting of 5 leaves each, in a single growth experiment.

Protein isolation and purification. Leaf samples (ca $1 \mathrm{~g}$ fresh weight) were ground to a fine powder in liquid nitrogen using mortar and pestle. Then proteins were extracted according to Giavialisco and others (Giavialisco et al., 2003, modified) protocol, in 5:1, v/w portions of extraction buffer consisted of $8 \mathrm{M}$ Urea, $2 \mathrm{M}$ Thiourea, 2\%, w/v C7BzO (Sigma), 2\%, v/v IPG Buffer (Amersham), $50 \mathrm{mM}$ DTT and $1 \%, \mathrm{v} / \mathrm{v}$ proteinase inhibitors cocktail (Sigma, P 9599). After samples centrifugation at $4^{\circ} \mathrm{C}$ and $18000 \mathrm{rpm}$ for $10 \mathrm{~min}$, protein concentration in the obtained supernatant was determined by the Bradford method (Bradford, 1976). Protein quantification was performed in triplicates against a standard curve of bovine serum albumin (BSA). Aliquots of proteins $(500 \mu \mathrm{g})$ were stored at $-80^{\circ} \mathrm{C}$ until further assay. Before analysis, each portion was purified via unspecific precipitation with Proteo Precipitation Kit (Sigma) according to the given protocol. Obtained pellet was resuspended in $0.5 \%$ IPG Buffer NL 3-10 (Amersham).

Two-dimensional gel electrophoresis. Protein samples were analyzed in triplicates. The aliquots were thawed, mixed with $3.2 \mu$ l of ampholytes ( $\mathrm{pH} 3-10)$, adjusted to the final volume of $315 \mu \mathrm{l}$ with the Isoelectrofocusing (IEF) sample solution and then loaded onto immobilized $\mathrm{pH}$ gradient (IPG) strips ( $\mathrm{pH} 4-7$, $18 \mathrm{~cm}$, non-linear gradient, Amersham Biosciences) in an isoelectric focusing unit (Ettan ${ }^{\mathrm{TM}}$ IPGphor II ${ }^{\mathrm{TM}}$, Amersham Biosciences). IEF was performed according to Berkelman \& Stendstedt (2004) protocol at $20^{\circ} \mathrm{C}$ for 20 h. After the first dimension IPG strips were equilibrated for $15 \mathrm{~min}$ in $5 \mathrm{ml}$ of SDS equilibration buffer (1.5 M Tris-HCl pH 6.8, 6 M Urea, 30\% (v/v) glycerol, $5 \%(\mathrm{w} / \mathrm{v})$ SDS) with $2 \%(\mathrm{w} / \mathrm{v})$ DTT followed by $15 \mathrm{~min}$ with the same buffer but containing $2.5 \%(\mathrm{w} / \mathrm{v})$ iodoacetamide (IAA) instead of DTT. The strips were then transferred onto $12.5 \%$ SDS-polyacrylamide gels and overlayed with $0.5 \%(\mathrm{w} / \mathrm{v})$ agarose in SDS running buffer with some addition of bromophenol blue as tracking dye. The second dimension electrophoresis was conducted according to Berkelman \& Stendstedt (2004) at $10^{\circ} \mathrm{C}$ at $10 \mathrm{~mA} /$ gel until the dye front reached the bottom of the gel (approx. $16 \mathrm{~h}$ ) by using Ettan Dalt Six electrophoresis unit (Amersham Biosciences). Simultaneously, molecular mass marker $10-200 \mathrm{kDa}$ (PageRuler ${ }^{\mathrm{TM}}$ Pro- 
tein Lader, Fermentas) was run. Gels were stained overnight in Colloidal Coomassie Brilliant Blue (CBB G-250) (Sigma) according to given protocol and digitalized using Image Scanner (Amersham Biosciences).

Analysis of protein expression. Image analyses (normalization, spot matching, expression analyses and statistics) were performed with PDQuest 8.0 software (Bio-Rad). First, images of gels were inverted, centralized and cropped using the same anchor spot, then the correlation coefficient between replicates was checked. The Master Gel was selected automatically and used for all bioinformatics analysis. The spot relative intensities were normalized to the total density in the gel images. Based on the MW of PR proteins reported in the literature, soluble proteins in the range of $13 \mathrm{kDa}$ to $50 \mathrm{kDa}$ were analysed using the software. One-way ANOVA statistical analysis was performed with a $95 \%$ significance level to determine which protein species were differentially abundant between the samples collected from control and cold-hardened plants of both genotypes. On the basis of the above calculations, spots showing a statistically significant $(p<0.05)$ increase or decrease in abundance (at least 2-fold) were selected and manually picked for digestion and identification.

Mass spectrometric identification of the protein species. Proteins were in-gel digested with trypsin according to the protocol described by Shevchenko and others (Shevchenko et al., 1996). The extracts of the obtained tryptic peptides were then spotted onto an AnchorChip target plate (MTP AnchorChip 384 T F, Bruker) and left to dry at ambient temperature. The anchors were subsequently covered with a solution of $\alpha$-cyano-4-hydroxycinnamic acid $(0.7 \mathrm{mg}$ CHCA in $85 \%$ ACN, $15 \% \mathrm{H}_{2} \mathrm{O}, 0.1 \%$ TFA and $1 \mathrm{mM} \mathrm{NH}_{4} \mathrm{H}_{2} \mathrm{PO}_{4}$ ) and again left to dry. All spectra were collected using ultrafleXtreme MALDI-TOF/TOF mass spectrometer and Compass 1.3 software for instrument control and data processing (both from Bruker Daltonik, Bremen, Germany). MS spectra were acquired in positive reflectron mode and externally calibrated using Peptide Calibration Standard II (Bruker). Fragment spectra were obtained by post-source decay (PSD) and internally calibrated on immonium ions. Protein identification was based on the peptide mass fingerprint confirmed by fragment spectra (PMF + MS/MS). MS and PSD spectra were peakpicked in flexAnalysis 3.3, sent to BioTools 3.2 (both Bruker software packages) and submitted to database search with the use of Mascot 2.4 (Matrix Science, London, England, http://www.matrixscience.com) in-house server. Five custom databases were created for this purpose based on the protein databases for Triticosecale (120 entries), Secale (945 entries), Triticum (50862 entries), Aegilops (39589 entries) and Hordeum (38447 entries), taken from NCBI Taxonomy Browser. MS and MS/MS mass tolerance was $50 \mathrm{ppm}$ and $0.5 \mathrm{Da}$, respectively. The identification results obtained were examined in terms of the score level (greater than 64) and the number of matched peptides (more than 2).

Surface-Enhanced Laser Desorption/Ionization (SELDI) and data analysis. The protocol for protein pattern analysis was performed according to Tang and others (Tang et al., 2004, modified), using different protein chips (microcolumns): NP20 (neutral), HP50 (hydrophobic), CM10 (exchanging weak cations) and Q10 (exchanging strong anions). Samples (1-10 $\mu \mathrm{l})$ of crude leaf extracts prepared in $10 \mathrm{mM}$ Tris $/ \mathrm{HCl} \mathrm{pH}=7.0$ buffer were analysed in 5 replicates for both control non-hardened and cold-hardened plants in the Protein Biological System II mass spectrometer reader (Ciphergen Biosystems, Fremont, CA). Peak detection accurate to the second decimal place was performed using ProteinChip Software 3.1 (Ciphergen Biosystems, Fremont, CA). The molecular mass below 2000 Da was eliminated from analysis because this area contains adducts and artifacts of the Energy Absorbing Molecule (EAM) and possibly other chemical contaminants. The spectra of samples generated under the same condition were grouped together and baseline subtracted then normalized to the total ion current of $\mathrm{m} / \mathrm{z}$ starting from 1500 Da. Peak information was exported into MS Excel and peak intensity was calculated for each spectrum. Differences among the means were statistically examined with a Student's $t$-test using STATISTICA ${ }^{\circledR}$ version 13.0 software at $p<0.05$.

\section{RESULTS}

In the 2-DE electrophoregrams of winter triticale seedling leaves, the mean total number of 470 soluble proteins ranged from $13 \mathrm{kDa}$ to $200 \mathrm{kDa}$ was found. In the present analysis, 2-DE profiles of 360 soluble proteins sized from $13 \mathrm{kDa}$ to $50 \mathrm{kDa}$ were compared between biological replicates and between different genotypes/treatments. Within this protein group, quantitative differences in protein abundance were observed for proteins of different MW (14 kDa to $50 \mathrm{kDa})$ and $\mathrm{pI}$ (4.6 to 7.0 ) (Table 1 ). No qualitative changes were noted between the experimental objects.

In cold-hardened seedling leaves of the snow mould tolerant $\mathrm{cv}$. Hewo, increased mean content of twelve proteins and decreased mean content of ten proteins were observed in comparison to the non-hardened control plants of this genotype (Table 1). Among cold-accumulated proteins, two chloroplastic enzymes 2-Cys peroxiredoxin BAS1 and Thioredoxin peroxidase, as well as ADP-binding resistance protein, were identified (Table 2, Fig. 1A). Proteins with the lowered concentration after exposure to the low temperature were identified as chloroplastic Ribulose bisphosphate carboxylase small chain

Table 1. The number of spots showing quantitative changes in abundance in leaves of model winter triticale seedlings.

\begin{tabular}{llllll}
\hline Comparison & $\begin{array}{l}\text { Differential } \\
\text { spots }\end{array}$ & $\begin{array}{l}\geq 2 \text {-fold up-regulated } \\
\text { spots* }(\%)\end{array}$ & $\begin{array}{l}\text { 22-fold down-regulated } \\
\text { spots* (\%) }\end{array}$ & $\begin{array}{l}\text { MW } \\
{[\mathrm{kDa}]}\end{array}$ & $\mathrm{pl}$ \\
\hline A: Hewo cold-hardened vs. control & 22 & $12(55 \%)$ & $10(45 \%)$ & $15-50$ & $4.6-6.8$ \\
\hline B: Magnat cold-hardened vs. control & 34 & $29(85 \%)$ & $5(15 \%)$ & $16-50$ & $4.6-6.5$ \\
\hdashline C: Control: Hewo vs. Magnat & 10 & $7(70 \%)$ & $3(30 \%)$ & $16-50$ & $4.9-6.7$ \\
\hline D: Cold-hardened: Hewo vs. Magnat & 12 & $6(50 \%)$ & $6(50 \%)$ & $14-49$ & $4.9-7.0$ \\
Total & 78 & $54(69 \%)$ & $24(31 \%)$ & $14-50$ & $4.6-7.0$ \\
\hline
\end{tabular}

${ }^{*}$ Change in abundance was calculated by dividing the mean \%vol of a spot in leaves of plants of the first object to mean \%vol of that spot in leaves of plants of the second one. 


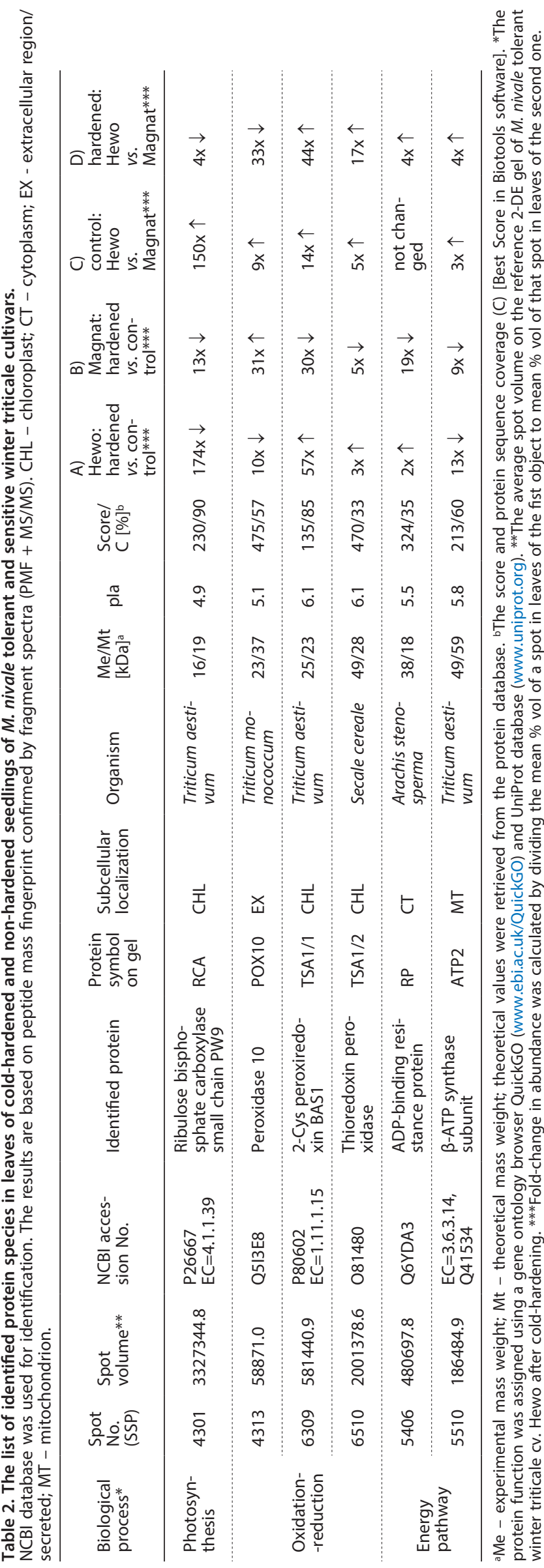

PW9, extracellular/secreted Peroxidase 10 and mitochondrial $\beta$-ATP synthase subunit (Table 2, Fig. 1A).

After hardening of the sensitive cv. Magnat seedlings, the increased accumulation of twenty-nine proteins and decreased accumulation of five proteins were noted in comparison to the control plants of this genotype (Table 1). Among identified proteins, only peroxidase 10 showed increased level after cold-hardening, while five remaining: chloroplastic Ribulose bisphosphate carboxylase small chain PW9, 2-Cys peroxiredoxin BAS1 and Thioredoxin peroxidase, as well as mitochondrial $\beta$-ATP synthase subunit and ADP-binding resistance protein, revealed decreased concentration in comparison to the control plants (Table 2, Fig. 1B).

Differences between cv. Hewo and cv. Magnat control seedlings involved seven proteins with the increased concentration as well as other three proteins with the decreased abundance (Table 1). Leaves of the control cv. Hewo seedlings showed a higher concentration of peroxidase 10, Ribulose bisphosphate carboxylase small chain PW9, 2-Cys peroxiredoxin BAS1, Thioredoxin peroxidase as well as $\beta$-ATP synthase subunit when compared to cv. Magnat non-hardened plants (Table 2, Fig. 1C).

In cold-hardened plants, differences between the model genotypes included six proteins with the increased and six proteins with the decreased expression level (Table 1). Among them, four proteins with the higher abundance in $\mathrm{cv}$. Hewo leaves were identified as

2-Cys peroxiredoxin BAS1, Thioredoxin peroxidase, ADP-binding resistance protein and $\beta$-ATP synthase subunit (Table 1, Fig. 1D). Proteins with the decreased level after cold-hardening in tolerant genotype in comparison to sensitive one were identified as Ribulose bisphosphate carboxylase small chain PW9 and Peroxidase 10 (Table 2, Fig. 1D).

SELDI-TOF analysis of the same plant samples revealed the presence of twenty-one low molecular weight proteins $(4.3-10.7 \mathrm{kDa})$ with the majority of them visible on CM10 columns (Table 3). After cold-hardening, only quantitative changes in the concentration of those molecules were noted in both triticale cultivars (Table 3). Cold-hardened seedling leaves of tolerant $\mathrm{cv}$. Hewo showed the increased mean concentration of seven proteins (ST23, ST6-7, ST13-14 and ST21) and the decreased mean concentration of four proteins (ST1, ST12, ST15 and ST20), when compared to the non-hardened control plants of this genotype (Table 3A). In sensitive cr. Magnat plants those changes involved twelve (ST1-3, ST5-6, ST11, ST13-17 and ST21) and three (ST8, ST12 and ST20) proteins, accordingly (Table 3B). In control plants of cv. Hewo the concentration of ten proteins (ST1, ST3-4, ST6, ST8 and ST13-17) was increased whereas the concentration of three proteins (ST10-12) was decreased in relation to the control plants of $\mathrm{cv}$. Magnat (Table 3C). After cold hardening, four proteins (ST3, ST6 and ST13-14) had higher and seven (ST5, ST11-12, ST15-17 and ST21) had a lower level in cv. Hewo leaves in comparison to cv. Magnat cold-hardened plants (Table 3D). After exposure to the low temperature, the maximal experimental differences between cv. Hewo and cv. Magnat leaf profiles were found for ST6 protein $(6.8 \mathrm{kDa}, 203 \%)$ as well as ST15 protein $(8.9 \mathrm{kDa}, 32 \%)$. The concentration of 
HARDENED

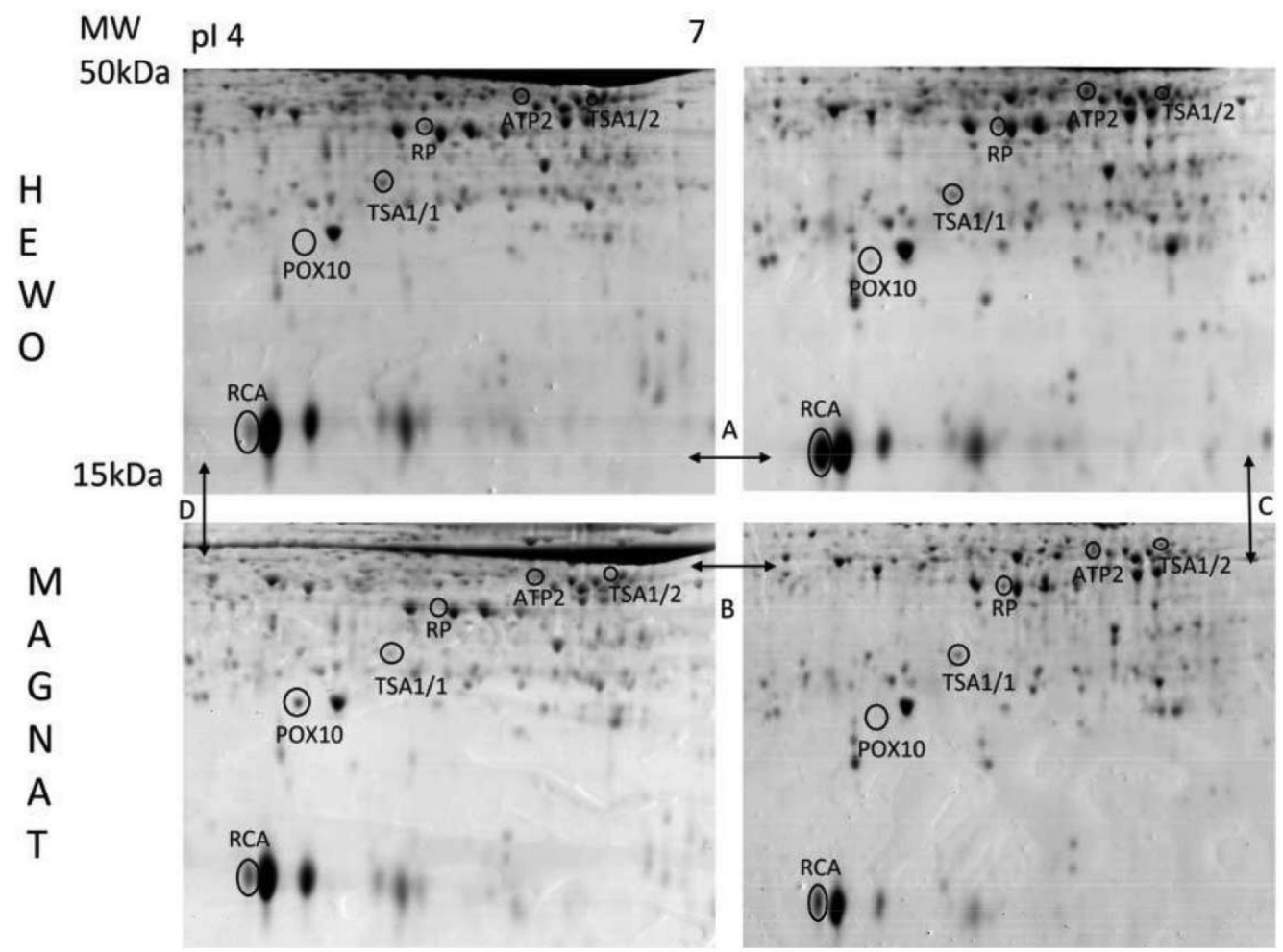

Figure 1. The comparison of soluble $14-50 \mathrm{kDa}$ leaf protein 2-DE profiles between winter triticale (xTriticosecale Wittmack) seedlings of:

(A) snow mould tolerant cv. Hewo, cold-hardened vs. non-hardened control; (B) snow mould sensitive cv. Magnat, cold-hardened vs. non-hardened control; (C) cv. Hewo vs. cv. Magnat non-hardened control; (D) cv. Hewo vs. cv. Magnat cold-hardened plants. Circles indicate the position of identified protein species differentially abundant in compared objects. Spot details are described in Table 2 . Abbreviations: ATP2 - $\beta$-ATP synthase subunit, mitochondrial; POX10 - peroxidase 10, extracellular/secreted; RCA - Ribulose bisphosphate carboxylase small chain PW9, chloroplastic; RP - 38 kDa ADP-binding resistance protein; TSA1/1 - 2-Cys peroxiredoxin BAS1, chloroplastic; TSA1/2 - Thioredoxin peroxidase, chloroplastic.

ST4, ST9, ST10, ST18-19 was not changed by hardening in leaves of both genotypes, additionally, ST9, ST18-19 proteins had equal level in all experimental objects ( $\mathrm{Ta}$ ble 3).

\section{DISCUSSION}

In our experiments, the exposure to the low temperature $\left(4\right.$ weeks at $\left.4^{\circ} \mathrm{C}\right)$ caused only quantitative changes in the protein patterns of seedling leaves of the two model winter triticale cultivars. Those changes included either increase or decrease of $4.3-10.7 \mathrm{kDa}$ and $14-50 \mathrm{kDa}$ soluble protein concentration, detected via SELDI-TOF and 2-DE analysis, accordingly (Tables 1 and 3).

The group of proteins with the cold-caused abundance drop was better represented in 2-DE profiles of snow mould tolerant cv. Hewo seedling leaves, while in sensitive $\mathrm{cv}$. Magnat plants many proteins revealed increased abundance after hardening (Table 1). A similar effect was observed by Golebiowska-Pikania et al. (2017) in winter barley seedlings: the maximal number of up-regulated proteins in hardened ( 20 days at $4 / 2^{\circ} \mathrm{C}$ ) plants was observed for the most freezing-sensitive $\mathrm{DH}$ line while the minimal for the freezing-tolerant one. This may suggest the strong low-temperature stress occurring in sensitive genotypes. Additionally, in present experiments, after exposure to the low temperature, changes of Peroxidase 10, 2-Cys peroxiredoxin BAS1, Thioredoxin peroxidase and ADP-binding resistance level in tolerant cv. Hewo plants had the opposite direction in comparison to the sensitive cv. Magnat (Table 2).

Even without hardening, Ribulose bisphosphate carboxylase small chain PW9, Peroxidase 10, 2-Cys peroxiredoxin BAS1, Thioredoxin peroxidase, and $\beta$-ATP synthase subunit had different (higher) abundance in $\mathrm{cv}$. Hewo leaves in comparison to cv. Magnat ones (Table 2). Among identified proteins, only $38 \mathrm{kDa}$ protein with homology to ADP-binding $18 \mathrm{kDa}$ resistance protein showed no difference in abundance between model cultivars without hardening (Table 2). On the contrary, after cold treatment, its content increased in cv. Hewo seedlings leaves and it had a higher level in relation to $\mathrm{cv}$. Magnat plants growing under the same conditions. This protein with an unknown function was described by Bertioli and others (Bertioli et al., 2003) in peanut (Arachis stenosperma) young leaves. In our experiment its increase was cold-specific.

The other protein cold-accumulated in plants of tolerant winter triticale genotype, 2-Cys peroxiredoxin BAS1 is homologous to a chloroplastic thiol-specific antioxidant $23 \mathrm{kDa}$ protein found in wheat leaves by Tsunoya$\mathrm{ma}$ and others (Tsunoyama et al., 1996). The Cys-64-SH group of this enzyme was indicated as the primary site of oxidation by hydrogen peroxide, and the oxidized Cys-64 rapidly reacts with Cys-185-SH of the other subunit to form an intermolecular disulfide, which might subsequently be reduced by thioredoxin (Tsunoyama et al., 1996). In our work, we also identified the second thioredoxin peroxidase, with increased accumulation in $\mathrm{cv}$. 
Table 3. The comparison of SELDI-TOF protein profiles of the winter triticale seedling leaves.

$\uparrow$ - increased accumulation; $\downarrow$ - decreased accumulation of individual protein; $n / c$ - not changed.

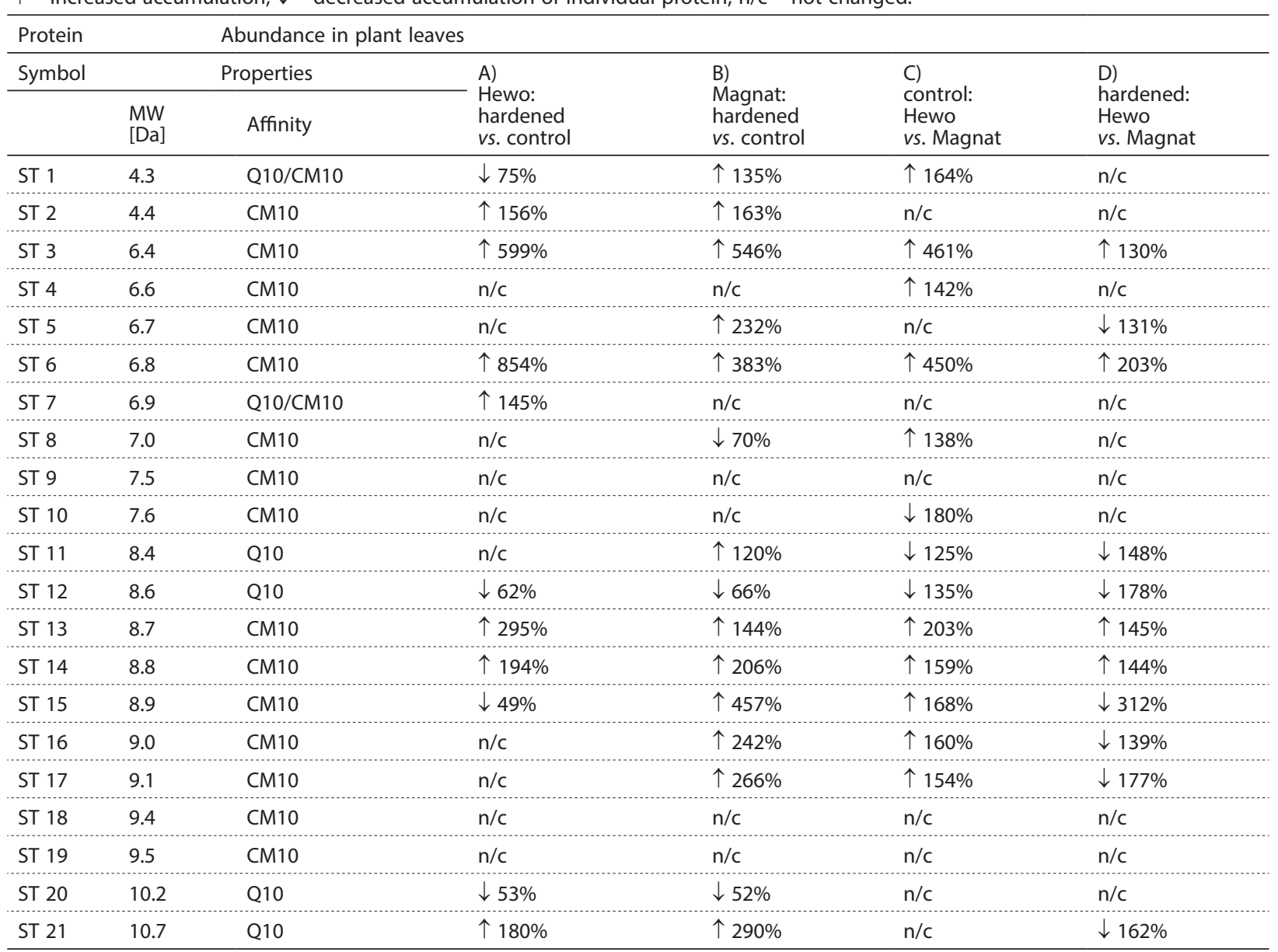

Hewo hardened seedling leaves, with homology to 28 $\mathrm{kDa}$ rye protein (Berberich et al., 1998). Cold-enhanced Tsa gene expression of the foliar thiol-specific antioxidant protein in $M$. nivale tolerant winter triticale seedlings after 4 weeks of chamber culture at $4^{\circ} \mathrm{C}$ was also previously documented in our qPCR analysis (Gołębiowska-Pikania \& Golemiec, 2015). In seedling leaves of cv. Hewo growing in the same hardening conditions we showed lower cold-mediated accumulation of hydrogen peroxide as well as a higher increase in the total unspecific peroxidase activity in comparison to $\mathrm{cv}$. Magnat plants (Gołębiowska et al., 2011). Other authors reported a protective role of 2-Cys peroxiredoxins in photosynthesis (Baier \& Dietz, 1999; Horling et al., 2002) and in oxidative stress-dependent switching from the peroxidase to molecular chaperone function (Jang et al., 2004), including the plant cellular defensive signaling mechanisms against oxidative stress (Jang et al., 2006). 2-Cys PRXs can interact with at least 18 other proteins and regulate them by their redox state as described in Rhee \& Woo review (Rhee \& Woo, 2011). On the basis of the above results, it can be assumed that in the tolerant cv. Hewo seedlings the cold-caused increased production of hydrogen peroxide is balanced by the thioredoxin peroxidases activity which we confirmed by spectrophotometric, qPCR and proteomic analyses.

In cv. Hewo leaves, the $\beta$-ATP synthase subunit had also higher level in cold-hardened plants, and it is homologous to wheat mitochondrial $59 \mathrm{kDa}$ chain with the molecular function of creating ATP from ADP in the presence of a proton gradient across the membrane (Abulafia et al., 1996). Such a result may suggest increased energy production at low temperature in snow mould tolerant genotypes.

On the contrary, in hardened cv. Hewo plants we showed a decreased level of RuBisCO small subunit PW9 and peroxidase 10 in comparison to $\mathrm{cv}$. Magnat ones (Table 1). The first protein was discovered in wheat chloroplast by Broglie and others (Broglie et al., 1993) as a $19 \mathrm{kDa}$ transit protein, belonging to RuBisCO small chain family. It was reported that protein expression of this subunit decreases in leaves of winter rape moved to cold-hardening conditions but increases in young leaves expanding at the low temperature (Singh \& Johnson-Flanagan, 1994). Similarly to our results, other authors also observed in 2-DE profiles a decreased accumulation of several photosynthesis-related proteins in winter wheat subjected to 63 day-long hardening at $4^{\circ} \mathrm{C}$ (Rinalducci et al., 2011). The decrease in susceptibility to photoinhibition exhibited following cold-hardening of winter and spring cultivars of wheat was not due to an increased capacity of repair of photoinhibitory damage at $5^{\circ} \mathrm{C}$ but reflected intrinsic properties of the cold-hardened photosynthetic apparatus (Hurry \& Huner, 1992). The down-accumulated peroxidase 10 identified by us was homologous to $37 \mathrm{kDa}$ class III peroxidase extracted from the powdery mildew-attacked epidermis of einkorn wheat (Triticum monococcum), involved in response to oxidative stress (Liu et al., 2005). 
Similarly to the results described above, only quantitative changes caused by the low temperature on protein concentration were noted in SELDI-TOF analysis (Table 3). Like in 2-DE profiles, more proteins with the increased concentration were present in leaves of cold-hardened plants of $\mathrm{cv}$. Magnat in comparison to non-hardened control of this genotype than in the similar comparison performed for cv. Hewo seedlings, while the number of proteins with the decreased level was almost equal (Table 3A, B). In leaves of both genotypes, the concentration of ST2-3, ST6, ST13-14 and ST21 increased and the concentration of ST12 and ST20 decreased after cold-hardening (Table 3A,B). Among those proteins, ST3 (6.4 kDa), ST6 (6.8 kDa), ST13 (8.7 kDa) and ST14 $(8.8 \mathrm{kDa})$ had a higher concentration and ST12 had a lower concentration in cv. Hewo both in cold-hardened and non-hardened plants in relation to similarly treated cv. Magnat ones (Table 3C, D). Additionally, ST5, ST11, ST15-17 and ST21 revealed lower level in cold-hardened cv. Hewo plants in comparison to cold-hardened plants of cv. Magnat (Table 3D). Even without hardening - in control plants of cv. Hewo proteins: ST1, ST4, ST8 and ST15-17 had higher level and ST10-11 had lower level in relation to control cv. Magnat plants (Table 3C). It can be assumed, that several low mass proteins were better represented in cold-hardened cv. Hewo plants in comparison to cv. Magnat ones and the impact of both genotype and temperature on their concentration was detected in our experiment.

Based on the above results we conclude that genotype and cold treatment significantly influenced the quantity of the small proteins in winter triticale seedling leaves. The pattern of these proteins could be correlated with the level of the resistance to pink snow mould infection. Four cold-accumulated proteins: ADP-binding 38 $\mathrm{kDa}$ resistant protein, $\beta$-ATP synthase subunit, as well as $25 \mathrm{kDa}$ and $49 \mathrm{kDa}$ thioredoxin peroxidases, may possibly play a role in the plant preparation before fungal pathogen attack in tolerant winter triticale cultivar by maintaining the red/ox balance and energy pathway in seedling leaves. Present studies may indicate molecules for the further analysis of $M$. nivale pathogenesis process in winter cereals.

\section{REFERENCES}

Abulafia S, Devos GD, Breiman A (1996) Characterization of the wheat cDNA encoding the $\alpha$ subunit of the mitochondrial ATP synthase. Isr J Plant Sci 44: 77-88. https://doi.org/10.1080/07929 978.1996 .10676637

Arseniuk E, Góral, T (2015) Triticale biotic stresses - known and novel foes. In Triticale, pp 83-108. Springer, Cham

Baier M, Dietz KJ (1999) Protective function of chloroplast 2-cysteine peroxiredoxin in photosynthesis. Evidence from transgenic Arabidopsis. Plant Physiol 119: 1407-1414.

https://doi.org/10.1104/pp.119.4.1407

Berberich T, Uebeler M, Feierabend J (1998) Cloning of a cDNA Encoding a Thioredoxin Peroxidase Homolog from Winter Rye (Accession No. AF076920) (PGR98-167) Plant Physiol 118: 711-711

Berkelman T, Stendstedt T (2004) 2-D Electrophoresis, Principles and methods. Handbook, Amersham Biosciences, 80-6429-60, pp 15-168

Bertioli DJ, Leal-Bertioli SC, Lion MB, Santos VL, Pappas GJr, Cannon SB, Guimaraes PM (2003) A large scale analysis of resistance gene homologues in Arachis. Mol Genet Genomics 270: 34-45. https:// doi.org/10.1007/s00438-003-0893-4

Bradford MM (1976) A rapid and sensitive method for the quantitation of microgram quantities of protein utilizing the principle of protein-dye binding. Anal Biochem 72: 248-54.

Broglie R, Coruzzi G, Lamppa G, Keith B, Chua NH (1983) Structural analysis of nuclear genes coding for the precursor to the small subunit of wheat ribulose-1,5-bisphosphate carboxylase. Biotechnology (N.Y.) 1: 55-61. https://doi.org/10.1038/nbt0383-55
Browne RA, Mascher F, Golebiowska G, Hofgaard IS (2006) Components of partial disease resistance in wheat detected in a detached leaf assay inoculated with Microdochium majus using first, second and third expanding seedling leaves. J Phytopathol 154: 204-208. https:// doi.org/10.1111/j.1439-0434.2006.01084.x

Cichy H, Maćkowiak W (1993) Intravarietal differences in winter triticale resistance to snow mould - Fusarium nivale. Hodowla Roślin, Aklimatyracja i Nasiennictwo 37: 115-119

Dubas E, Golebiowska G, Zur I, Wedzony M (2011) Microdochium nivale (Fr., Samuels \& Hallett): cytological analysis of the infection process in triticale (x Triticosecale Wittm.) Acta Physiol Plant 33: 529537. https://doi.org/10.1007/s11738-010-0576-9

Ergon A, Klemsdal S, Tronsmo AM (1998) Interactions between cold hardening and Microdochium nivale infection on expression of pathogenesis-related genes in winter wheat. Physiol Mol Plant Pathol 53: 301-310. https://doi.org/10.1006/pmpp.1998.0182

Ergon $\AA$, Tronsmo AM (2006) Components of pink snow mould resistance in winter wheat are expressed prior to cold hardening and in detached leaves. J Phytopathol 154: 134-142. https://doi. org/10.1111/j.1439-0434.2006.01071.x

Gaudet DA, Laroche A, Frick M, Davoren J, Puchalski B, Ergon A (2000) Expression of plant defense-related (PR-protein) transcripts during hardening and dehardening of winter wheat. Physiol Mol Plant Pathol 57: 15-24. https://doi.org/10.1006/pmpp.2000.0275

Gaudet DA, Laroche A, Frick M, Huel R, Puchalski B (2003a) Cold induced expression of plant defensin and lipid transfer protein transcripts in winter wheat. Physiol Plantarum 117: 195-205. https://doi. org/10.1034/j.1399-3054.2003.00041.x

Gaudet DA, Laroche A, Frick M, Huel R, Puchalski B (2003b) Plant development affects the cold-induced expression of plant defenserelated transcripts in winter wheat. Physiol Mol Plant Pathol 62: 175184. https://doi.org/10.1016/S0885-5765(03)00025-0

Gawrońska K, Gołębiowska-Pikania G (2016) The effects of cold-hardening and Microdochium nivale infection on oxidative stress and antioxidative protection of the two contrasting genotypes of winter triticale. Eur Food Res Technol 242: 1267-1276. https://doi. org/10.1007/s00217-015-2630-8

Giavalisco P, Nordhoff E, Lehrach H, Gobom J, Klose J (2003) Extraction of proteins from plant tissues for two dimensional electrophoresis analysis. Electrophoresis 24: 207-216. https://doi. org/10.1002/elps.200390016

Gołębiowska G, Wędzony M (2009) Cold-hardening of winter triticale (x Triticosecale Wittm.) results in increased resistance to pink snow mould Microdochium nivale (Fr., Samuels \& Hallett) and genotype-dependent chlorophyll fluorescence modulations. Acta Physiol Plant 31: 12-19. https://doi.org/10.1007/s11738-009-0357-5

Gołębiowska G, Wędzony M, Plażek A (2011) The responses of proand antioxidative systems to cold-hardening and pathogenesis differs in triticale (xTriticosecale Wittm.) seedlings susceptible or resistant to pink snow mould (Microdochium nivale Fr., Samuels \& Hallett) J Phytopathol 159: 19-27. https://doi.org/10.1111/j.1439-0434.2010.01712.x

Golebiowska-Pikania G, Golemiec E (2015) Cold-enhanced gene expression of the foliar thiol-specific antioxidant protein in triticale ( $\mathrm{x}$ Triticosecale Wittm.) seedlings resistant to Microdochium nivale (Samuels and IC Hallett) infection. Zessyty Naukowe. Acta Biologica. Uniwersytet Szrzecinski, 22. https://doi.org/10.18276/ab.2015.22-08

Gołębiowska-Pikania G, Kopeć P, Surówka E, Krzewska M, Dubas E, Nowicka A, Rapacz M, Wójcik-Jagła M, Malaga S, Żur I (2017) Changes in protein abundance and activity involved in freezing tolerance acquisition in winter barley (Hordeum vulgare L.) J Proteomics 169: 58-72. https://doi.org/10.1016/j.jprot.2017.08.019

Hiilovaara-Teijo M, Hannukkala A, Griffith M, Tu X-M, PihakaskiMaunsbach K (1999) Snow-mould-induced apoplastic proteins in winter rye leaves lack antifreeze activity. Plant Physiol 121: 665-673. https://doi.org/10.1104/pp.121.2.665

Hoagland DR, Arnon DI (1938) A water culture method for growing plants without soil. Circ Univ Calif Agric Exp Stn No. 347

Horling F, König J, Dietz KJ (2002) Type II peroxiredoxin C, a member of the peroxiredoxin family of Arabidopsis thaliana: its expression and activity in comparison with other peroxiredoxins. Plant Physiol Biochem 40: 491-499. https://doi.org/10.1016/S0981-9428(02)01396-

Hömmo L (1994) Screening winter rye cultivars for snow mould ( $M i$ crodochium nivale) resistance. Plant Pathol 43: 740-750. https://doi. org/10.1111/j.1365-3059.1994.tb01614.x

Hudec K, Bokor P (2002) Field patogenicity of Fusarium culmorum, Fusarium equiseti and Microdochium nivale on triticale. Physiol Plantarum 115: $101-110$

Hurry VM, Huner NP (1992) Effect of cold hardening on sensitivity of winter and spring wheat leaves to short-term photoinhibition and recovery of photosynthesis. Plant Physiol 100: 1283-1290. https:// doi.org/10.1104/pp.100.3.1283

Jang HH, Lee KO, Chi YH, Jung BG, Park SK, Park JH, Lee JR, Lee SS, Moon JC, Yun JW, Choi YO, Kim WY (2004) Two enzymes in one: Two yeast peroxiredoxins display oxidative stress-dependent 
switching from a peroxidase to a molecular chaperone function. Cell 117: 625-635. https://doi.org/10.1016/j.cell.2004.05.002

Jang HH, Chi YH, Park SK, Lee SS, Lee JR, Park JH, Moon JC, Lee YM, Kim SY, Lee KO, Lee SY (2006) Structural and functional regulation of eukaryotic 2-Cys peroxiredoxins including the plant ones in cellular defense signaling mechanisms against oxidative stress. Physiol Plantarum 126: 549-559. https://doi.org/10.1111/ j.1399-3054.2006.00685.x

Kuwabara C, Takezawa D, Shimada T, Hamada T, Fujikawa S, Arakawa K (2002) Abscisic acid an antifungal activity against snow mould, Microdochium nivale. Physiol. Plantarum 115: 101-110

Laroche A, Gaudet DA, Audy P, Frick MM, Mullin J (1997) Induction of freezing tolerance and snow mould resistance in winter wheat: biochemical and molecular perspectives. Acta Agron Hung 45: 279283

Liu G, Sheng X, Greenshields DL, Ogieglo A, Kaminskyj S, Selvaraj G, Wei Y (2005) Profiling of wheat class III peroxidase genes derived from powdery mildew-attacked epidermis reveals distinct sequence-associated expression patterns. Mol Plant Microbe Interact 18: 730-741. https://doi.org/10.1094/MPMI-18-0730

Okushima Y, Koizumi N, Kusano T, Sano H (2000) Secreted proteins of tobacco cultured BY2 cells: identification of a new member of pathogenesis-related proteins. Plant Mol Biol 42: 479-488. https:// doi.org/10.1023/A:1006393326985

Prończuk M, Madej L, Kolasińska I (2003) Research for resistance to Microdochium nivale among inbred lines of rye. Plant Breeding \& Seed Science 48: 83-86

Ren R, Yang X, Ray RV (2015) Comparative aggressiveness of Microdochium nivale and $M$. majus and evaluation of screening methods for Fusarium seedling blight resistance in wheat cultivars. Eur J Plant Pathol 141: 281-294. https://doi.org/10.1007/s10658-014-0541-3

Rhee SG, Woo HA (2011) Multiple functions of peroxiredoxins: peroxidases, sensors and regulators of the intracellular messenger $\mathrm{H}_{2} \mathrm{O}_{2}$, and protein chaperones. Antioxidants \& Redox Signaling 15: 781-794. https://doi.org/10.1089/ars.2010.3393

Rinalducci S, Egidi MG, Mahfoozi S, Godehkahriz SJ, Zolla L (2011) The influence of temperature on plant development in a vernalization-requiring winter wheat: A 2-DE based proteomic investigation. J Proteomics 74: 643-659. https://doi.org/10.1016/j.jprot.2011.02.005

Shevchenko A, Wilm M, Vorm O, Mann M (1996) Mass spectrometric sequencing of proteins from silver-stained polyacrylamide gels. Anal Chem 68: 850-858. https://doi.org/10.1021/ac950914h

Singh J, White T (1994) Low Temperature Regulation of Gene Expression in winter Brassica napus. In Biochemical and Cellular Mechanisms of Stress Tolerance in Plants, pp 557-568. Springer, Berlin, Heidelberg

Sliesaravičius A, Pekarskas J, Baranauskis K (2006) Grain yield and disease resistance of winter cereal varieties and application of biological agent in organic agriculture. Agronomy Res 4 (Special issue): 371-378

Stricker S, Hsiang T, Bertrand A (2017) Reaction of bentgrass cultivars to a resistance activator and elevated $\mathrm{CO}_{2}$ levels when challenged with Microdochium nivale, the cause of Microdochium Patch. Int Turfgrass Soc Res J 13: 229-234. https://doi.org/10.2134/itsrj2016.08.0666

Szechyńska-Hebda M, Wędzony M, Tyrka M, Gołębiowska G, Chrupek M, Czyczyło-Mysza I, Dubas E, Zur I, Golemiec E (2011)
Identifying QTL for cold-induced resistance to Microdochium nivale in winter triticale. Plant Genetic Resources: Characterization and Utilization 9: 296-299. https://doi.org/10.1017/S1479262111000268

Szechyńska-Hebda M, Hebda M, Mierzwiński D, Kuczyńska P, Mirek M, Wędzony M, van Lammeren A, Karpiński S (2013) Effect of cold-induced changes in physical and chemical leaf properties on the resistance of winter triticale $(\times$ Triticosecale $)$ to the fungal pathogen Microdochium nivale. Plant Pathol 62: 867-878. https://doi. org/10.1111/ppa.12001

Szechyńska-Hebda M, Wąsek I, Gołębiowska-Pikania G, Dubas E, Żur I, Wędzony M (2015) Photosynthesis-dependent physiological and genetic crosstalk between cold acclimation and cold-induced resistance to fungal pathogens in triticale (Triticosecale Wittm.) J Plant Physiol 177: 30-43. https://doi.org/10.1016/j.jplph.2014.12.017

Tang N, Tornatore P, Weinberger SR (2004) Current developments in SELDI affinity technology. Mass Spec Rev 23: 34-44. https://doi. org/10.1002/mas.10066

Tronsmo AM, Hsiang T, Okuyama H, Nakajima T (2001) Low temperature diseases caused by Microdochium nivale. In: Low Temperature Plant Microbe Interactions Under Snow. Iriki N, Gaudet DA, Tronsmo AM, Matsumoto N, Yoshida M, Nishimune A eds, pp 75-86

Tsunoyama Y, Takashi S, Toyoshima Y (1996) Submitted (MAY-1996) to UniProtKB. Cited for: PROTEIN SEQUENCE OF 11-35. Strain: cv. Norin 61. Tissue: Leaf.

Tuzun S, Somanchi A (2006) The possible role of PR proteins in multigenic and induced systemic resistance. In: Multigenic and induced systemic resistance in plants. Tuzun S, Bent E eds, pp 51-67

Van Loon LC (1997) Induced resistance in plants and the role of plant pathogenesis-related proteins. Eur J Plant Pathol 103: 753-765. https://doi.org/10.1023/A:1008638109140

Van Loon LC, Van Strien EA (1999) The families of pathogenesis-related proteins, their activities, and comparative analysis of PR-1 type proteins. Physiol Mol Plant Pathol 55: 85-97. https://doi.org/10.1006/ pmpp.1999.0213

Van Loon LC, Rep M, Pieterse CM (2006) Significance of inducible defense-related proteins in infected plants. Annu Rev Phytopathol 44: 135-162

Yeh S, Moffatt BA, Griffith M, Xiong F, Yang DSC, Wiseman SB, Sarah F, Danyluk J, Xue YQ, Hew CL, Dotherty-Kirby A, Lajoie $\mathrm{G}$ (2000) Chitinase genes responsive to cold encode antifreeze proteins in winter cereals. Plant Physiol 124: 1251-1263. https://doi. org/10.1104/pp.124.3.1251

Zadoks JC, Chang TT, Konzak CF (1974) A decimal code for the growth stages of cereals. Weed Res 14: 415-421. https://doi. org/10.1111/j.1365-3180.1974.tb01084.x

Zhukovsky A, Ilyuk A (2010) Snow mould harmfulness in winter triticale and the efficiency of seed dressing products in the Republik of Belarus. Prog Plant Prot 50: 1841-1846 (in Polish)

Żur I, Gołębiowska G, Dubas E, Golemiec E, Matušíková I, Libantová J, Moravčiková J (2013) $\beta$-1,3-glucanase and chitinase activities in winter triticales during cold hardening and subsequent infection by Microdochium nivale. Biologia 68: 241-248. https://doi.org/10.2478/ s11756-013-0001-0 